


\section{PAS-referenties huisvesting landbouwhuisdieren}

Karin Groenestein, Andre Aarnink, Hilko Ellen, Sjoerd Bokma, Paul Bikker

Dit onderzoek is uitgevoerd door Wageningen Livestock Research, in opdracht van en gefinancierd door het Ministerie van Economische Zaken, in het kader van het Beleidsondersteunend onderzoek thema 'Mest en Milieu' (projectnummer BO-20-004-093).

Wageningen Livestock Research

Wageningen, juni 2017

Rapport 1083 
Karin Groenestein, Andre Aarnink, Hilko Ellen, Sjoerd Bokma, Paul Bikker, 2017. PAS-referenties huisvesting landbouwhuisdieren; Wageningen Livestock Research, Vertrouwelijk Rapport 1083.

Samenvatting. Dit rapport beschrijft uitvoering van- en management in stallen zoals dat in 2013 gangbaar was voor de belangrijkste categorieën landbouwhuisdieren. Deze dienen als referentie om het effect van maatregelen om ammoniakemissie te reduceren te kunnen kwantificeren in het kader van de Programmatische Aanpak Stikstof (PAS).

Summary UK. This report describes design of and management in animal housings common in 2013 for the main livestock categories. These serve as reference to quantify the effect of measures to reduce ammonia emissions within the framework of the Dutch national program PAS (Programmatische Aanpak Stikstof) to reduce nitrogen deposition in The Netherlands.

Dit rapport is gratis te downloaden op DOI : https://doi.org/10.18174/440791 of op www.wur.nl/livestock-research (onder Wageningen Livestock Research publicaties.

(c) 2017 Wageningen Livestock Research

Postbus 338, 6700 AH Wageningen, T 03174839 53, E info.livestockresearch@wur.nl, www.wur.nl/livestock-research. Wageningen Livestock Research is onderdeel van Wageningen University \& Research.

Wageningen Livestock Research aanvaardt geen aansprakelijkheid voor eventuele schade voortvloeiend uit het gebruik van de resultaten van dit onderzoek of de toepassing van de adviezen.

Alle rechten voorbehouden. Niets uit deze uitgave mag worden vermenigvuldigd en/of openbaar gemaakt worden door middel van druk, fotokopie, microfilm of op welke wijze dan ook zonder voorafgaande toestemming van de uitgever of auteur.

De certificering volgens ISO 9001 door DNV onderstreept ons kwaliteitsniveau. Op als onze onderzoeksopdrachten zijn de Algemene Voorwaarden van de Animal Sciences Group van toepassing. Deze zijn gedeponeerd bij de Arrondissementsrechtbank Zwolle.

Wageningen Livestock Research Rapport 1083 


\section{Inhoud}

$\begin{array}{ll}\text { Woord vooraf } & 5\end{array}$

1

$\begin{array}{ll}\text { Inleiding } & 7\end{array}$

2

$\begin{array}{ll}\text { Algemeen } & 8\end{array}$

2.1 Diercategorieën $\quad 8$

2.2 Referentie houderijsystemen $\quad 8$

3

$\begin{array}{ll}\text { Diercategorieën } & 9\end{array}$

3.1 Rundvee $\quad 9$

3.1.1 Melkvee 9

3.1.2 Jongvee 9

$\begin{array}{ll}3.1 .3 \text { Vleeskalveren } & 12\end{array}$

3.2 Varkens $\quad 15$

3.2.1 Biggen 15

$\begin{array}{ll}3.2 .2 \text { Kraamzeugen } & 16\end{array}$

$\begin{array}{ll}3.2 .3 \text { Guste en dragende zeugen } & 17\end{array}$

3.2.4 Vleesvarkens 18

$\begin{array}{lll}3.3 & \text { Pluimvee } & 19\end{array}$

3.3.1 Opfokleghennen 19

3.3.2 Leghennen 19

$\begin{array}{ll}\text { 3.3.3 Opfok vleeskuikenouderdieren } & 21\end{array}$

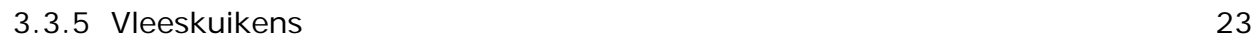





\section{Woord vooraf}

Om de effecten van stalmaatregelen in de Programmatische Aanpak Stikstof (PAS) te kunnen bepalen dient goed in kaart gebracht te worden wat de uitgangssituatie is. Daarom heeft het Ministerie van Economische zaken aan Wageningen UR Livestock Research gevraagd deze uitgangssituatie te beschrijven. Het Ministerie heeft daarbij bepaald dat 2013 geldt als referentiejaar. Dit rapport beschrijft voor de relevante diercategorieën de gemiddelde stal en de landbouwkundige randvoorwaarden van dat jaar.

Karin Groenestein (projectleider) 


\section{$1 \quad$ Inleiding}

PAS (Programmatische Aanpak Stikstof) is een initiatief van de Nederlandse overheid om samen met maatschappelijke partners de stikstofuitstoot te verminderen om de Natura 2000 gebieden te beschermen. Aanleiding tot deze aanpak is het vastlopen van de vergunningverlening. De Natuurbeschermingswet eist dat natuurdoelen veilig zijn. Het was aan de aanvrager om dat aan te tonen. Dit is lastig, zo niet onmogelijk, in 117 van de 161 Natura 2000 gebieden in Nederland is de depositie al te hoog. Stikstof wordt geëmitteerd door de industrie, door het verkeer en door de landbouw. Veehouderij komt veel voor in de buurt van Natura 2000 gebieden. De ammoniakemissie van die bedrijven is daarom extra in beeld.

PAS is in de uitvoering een systeem van maatregelen en afspraken. Het helpt bedrijven bij het aanvragen van vergunningen, monitort de stikstofdepositie lokaal en stuurt indien nodig bij. Specifiek voor de landbouw betekent PAS, naast hulp bij de vergunningaanvraag, een pakket aan maatregelen met betrekking tot voer, management, huisvesting en mesttoediening. In combinatie met herstelmaatregelen in de natuur moet dit naast reductie van de ammoniakdepositie ook ontwikkelruimte bieden voor het bedrijf. Het instrument dat PAS daarbij gebruikt is Aerius.

Om het effect van PAS-maatregelen te waarderen zijn referenties nodig. Dit is dus de uitgangssituatie die op $100 \%$ ammoniakemissie gesteld wordt. Dit onderzoek stelt de referenties voor huisvesting van landbouwhuisdieren vast waaraan de effecten van de maatregelen in de stallen worden gerelateerd. Afgesproken is dat het referentiejaar 2013 is.

In dit rapport zijn de stallen beschreven voor de diverse veehouderijcategorieën die voor 2013 als referentie beschouwd kunnen worden. Daar waar van toepassing voldoen de stallen aan de eisen van de welzijnsregelgeving zoals die zijn opgenomen in het Besluit houders van dieren. Dit besluit is de vervanger van diverse andere besluiten of verordeningen, waarin eisen ten aanzien van bijvoorbeeld oppervlakte per dier waren vastgelegd.

Voor meer informatie over PAS en het uitvoeringsinstrument Aerius wordt verwezen naar de website van het Ministerie van Economische Zaken (EZ): http://pas. natura2000.nl/. 


\section{$2 \quad$ Algemeen}

\section{$2.1 \quad$ Diercategorieën}

Er zijn in de Regeling ammoniak en veehouderij (Rav) veel diercategorieën opgenomen, van melkvee tot struisvogels. De diercategorieën die relevant zijn voor de PAS zijn opgenomen in deze rapportage. Diercategorieën en subcategorieën zijn relevant als verwacht mag worden dat de betreffende veehouders PAS-maatregelen gaan nemen en als het effect van die maatregelen herkenbaar in de berekeningen terug kunnen komen. Dit is afhankelijk van de grootte van het effect en het aantal dieren waarop het van toepassing is.

\subsection{Referentie houderijsystemen}

Per diersoort en - categorie wordt omschreven wat een typische huisvesting was in 2013. Typisch betekent hier niet een gemiddelde, maar het huisvestingssysteem dat toen het meeste gangbaar was. In de beschrijving van de systemen worden die factoren en aspecten gewaardeerd die direct aan maatregelen te koppelen zijn. Dit betekent bijvoorbeeld dat geen waarden opgenomen worden voor ammoniumconcentratie en geen maten voor bevuilde oppervlakken. Dit zijn namelijk resultanten van maatregelen en derhalve niet direct instelbaar zoals respectievelijk voereiwit en hokafmetingen. Deze worden wel opgenomen.

Als in de referentie systemen waarden bij aspecten zijn opgenomen, betekent dat, wanneer aspecten buiten die waarden komen, het een potentiele PAS-maatregel betreft. Een voorbeeld hiervan is groepsgrootte, andere voorbeelden zijn eiwitopname en waterverbruik. Om die reden worden in de beschrijving van referentie systemen ook geen bandbreedtes opgenomen, dat is niet toetsbaar. Indien nodig kan de referentie waarde wel onderbouwd worden met bandbreedtes. Dit impliceert bijvoorbeeld ook dat de verschillende mogelijkheden die het klimaatplatform aanreikt om een ruimte te ventileren, niet als zodanig worden opgenomen, maar vertaald worden naar een typisch ventilatiesysteem in 2013. Wanneer aspecten in de referentie systemen helemaal niet benoemd zijn, betekent dat die aspecten potentiele PAS-maatregelen zijn. Een voorbeeld hiervan is het gebruik van snijmaïs of turf als strooiselmateriaal bij vleeskuikens. Omdat deze niet worden genoemd bij de referenties, zijn het ( potentiele) PAS-maatregelen.

Vanwege consistentie in de tabellen in deze rapportage zijn soms ook variabelen opgenomen die voor de betreffende diercategorie niet relevant zijn. Dit is dan in de tabel aangegeven met n.v.t. (niet van toepassing).

Veel varkensbedrijven zijn uitgerust met een luchtwasser. Deze kun je dan beschouwen als een gangbaar systeem. Deze zijn in de referentie echter niet meegenomen, omdat maatregelen in de stal bij aanwezigheid van een luchtwasser slechts een gering effect op de ammoniakemissie hebben en daardoor niet kosteneffectief zijn.

Wanneer het effect van maatregelen getoetst moet worden aan de emissie van het referentiesysteem moet wel voorzien worden in de mogelijkheid het effect van de maatregel daadwerkelijk te kunnen monitoren. Gegeven beschrijving van de stalsystemen onder de huidige Rav emissiefactoren, en de rekenmethodiek en activiteitendata waar de monitoringstool vanuit gaat, is dat geen vanzelfsprekendheid. Deze rapportage voorziet hier niet in, dit vereist nadere beschouwing bij invoering van maatregelen. 


\section{Diercategorieën}

\subsection{Rundvee}

\subsubsection{Melkvee}

De huisvesting van melkvee is uniform over heel Nederland. De voeding laat echter duidelijke regionale verschillen zien. In de regio noord- en west-Nederland is het hoofdaandeel van het geconserveerde ruwvoer graskuil terwijl dit in het zuiden en oosten van Nederland snijmaïssilage is. Deze onderverdeling is zichtbaar gemaakt in tabel 1 .

Tabel $1 \quad$ PAS-referentie voor een stal voor melkvee

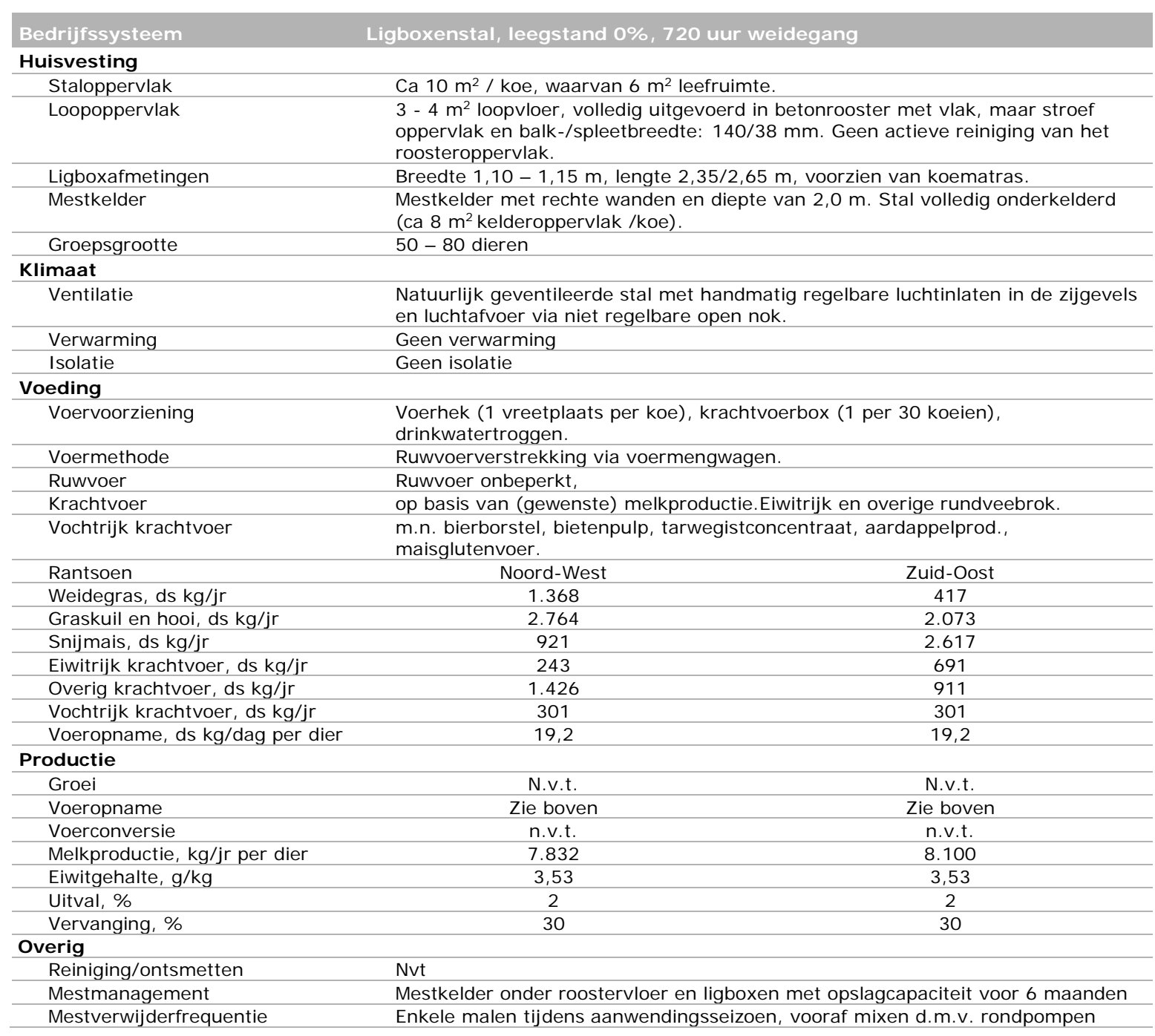

\subsubsection{Jongvee}

Pasgeboren kalveren, zowel de vaarsjes als stiertjes, worden de eerste twee weken individueel gehuisvest in kalverboxen of in kalver-iglo's buiten de stal. De eerste dagen ontvangen de kalveren biest van de eigen moeder. Daarna worden ze overgezet op kunstmelk. De stierkalfjes verlaten na 14 dagen het melkveebedrijf. De opfok van het vrouwelijk jongvee vindt overwegend op het melkveebedrijf zelf plaats. Het vrouwelijk jongvee groeit in 2 jaar tijd van een startgewicht van ca 45 $\mathrm{kg}$ naar een levend gewicht van ca $520 \mathrm{~kg}$. De huisvesting van het vrouwelijk jongvee is in de basis een hok met ligboxstal-opstelling dat "meegroeit" met de ontwikkeling van de dieren; de kalveren worden in die tijd 2 of 3 maal verplaatst naar een hok met ruimere voorzieningen. 
De huisvesting van jongvee is onderverdeeld in 3 perioden: tot ca 4 à 6 maanden; van 4 à 6 maanden tot 1 jaar en van 1 tot 2 jaar. Dit is gangbaar in de praktijk. Binnen de WUM-systematiek wordt de opfok onderverdeeld in 2 perioden; van 0 - 1 jaar en van 1 - 2 jaar. De Rav maakt geen onderscheid in fasen en kent maar 1 code voor alle vrouwelijk jongvee tot 2 jaar (A3). In tabel $2 a$ worden de eerste twee perioden van het eerste levensjaar beschreven en in tabel $2 \mathrm{~b}$ de periode van 1 tot 2 jaar.

Tabel 2a PAS Referentie voor een stal voor vrouwelijk jongvee (A3) 3 weken - 12 maanden

\begin{tabular}{|c|c|}
\hline \multirow[t]{2}{*}{ Bedrijfssysteem } & $\begin{array}{l}\text { Vrouwelijk jongvee van } 3 \\
\text { weken - } 4 \text { à } 6 \text { maanden }\end{array}$ \\
\hline & $\begin{array}{l}\text { Aparte kalverstal, geen } \\
\text { weidegang }\end{array}$ \\
\hline \multicolumn{2}{|l|}{ Huisvesting } \\
\hline Hokuitvoering & Strohok \\
\hline Loopoppervlak & $\begin{array}{l}\text { Ca } 3 \mathrm{~m}^{2} \text { ingestrooide leefruimte per } \\
\text { dier of ondiepe potstal met } \\
\text { betonrooster achter het voerhek. }\end{array}$ \\
\hline
\end{tabular}

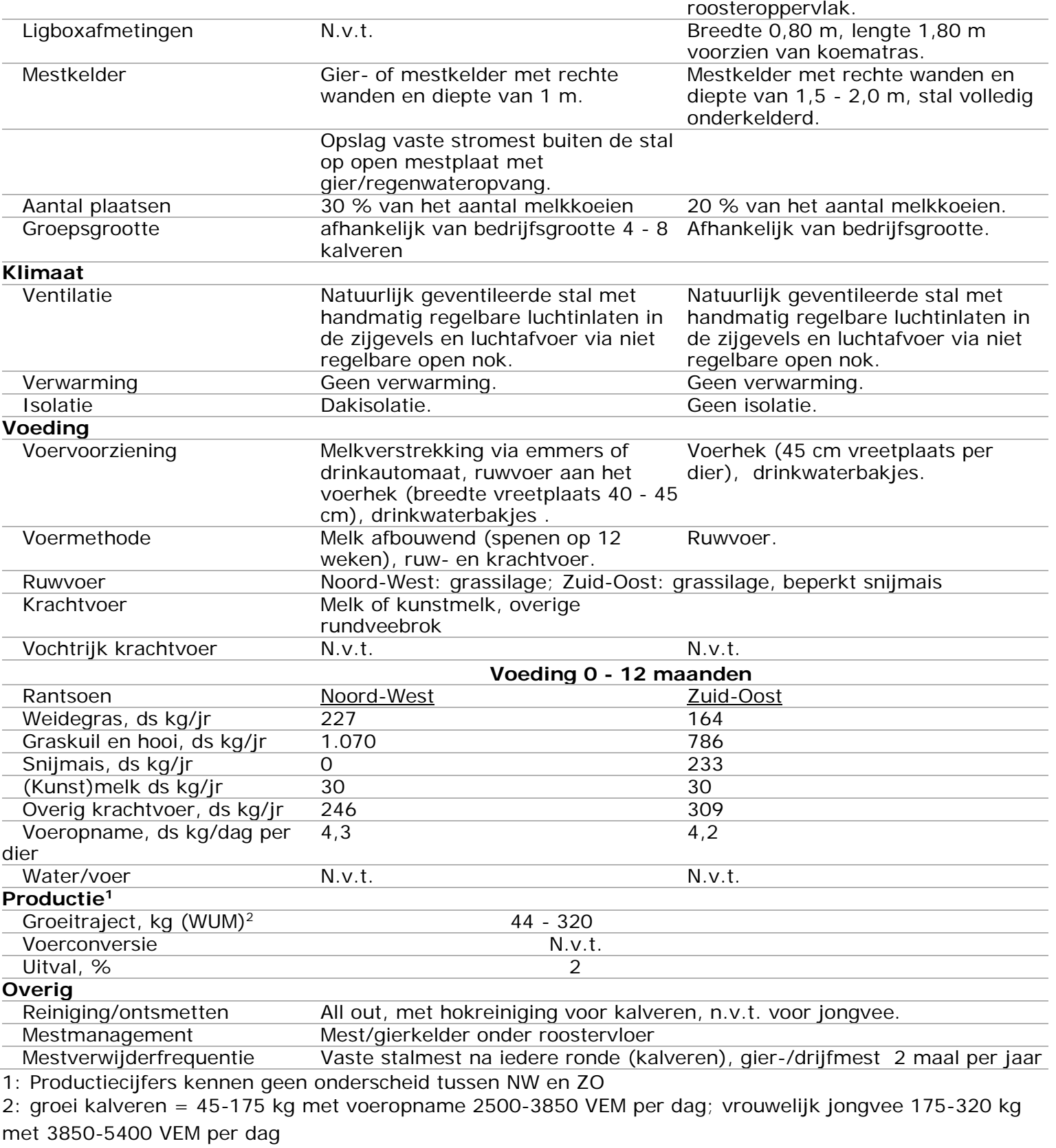

Ligboxenstal uitgevoerd in betonrooster met een vlak, maar stroef oppervlak en balk/spleetbreedte: 120/30 mm. Geen actieve reiniging van het roosteroppervlak. Breedte $0,80 \mathrm{~m}$, lengte $1,80 \mathrm{~m}$ voematras. diepte van $1,5-2,0 \mathrm{~m}$, stal volledig op open mestplaat met gier/regenwateropvang. \% van het aantal melkkoeien afhankelijk van bedrijfsgrootte 4 - 8 Afhankelijk van bedrijfsgrootte. Natuurlijk geventileerde stal met handmatig regelbare luchtinlaten in regelbare open nok. Geen verwarming.

Melkverstrekking via emmers of drinkautomaat, ruwvoer aan het $\mathrm{cm})$, drinkwaterbakjes. Melk afbouwend (spenen op weken), ruw- en krachtvoer. Melk of kunstmelk, overige rundveebrok N.v.t. Voerconversie Uitval, \% All out, met hokreiniging voor kalveren, n.v.t. voor jongvee. Mest/gierkelder onder roostervloer Vaste stalmest na iedere ronde (kalveren), gier-/drijfmest 2 maal per jaar 1: Productiecijfers kennen geen onderscheid tussen NW en ZO met 3850-5400 VEM per dag 
Tabel 2b

PAS Referentie voor een stal voor vrouwelijk jongvee (A3) 12 - 24 maanden

\begin{tabular}{|c|c|}
\hline Bedrifissysteem & Ligboxenstal, leegstand $0 \%$, weidegang in de zomer \\
\hline \multicolumn{2}{|l|}{ Huisvesting } \\
\hline Hokuitvoering & Ligboxenstal \\
\hline Loopoppervlak & $\begin{array}{l}2,5-3 \mathrm{~m} 2 \text { loopvloer, volledig uitgevoerd in betonrooster met een vlak, } \\
\text { maar stroef oppervlak en balk-/spleetbreedte: } 140 / 38 \mathrm{~mm} \text {. Geen actieve } \\
\text { reiniging van het roosteroppervlak. }\end{array}$ \\
\hline Ligboxafmetingen & Breedte 0,90 - 1,10 m, lengte 2,00 - 2,20 m., voorzien van koematras. \\
\hline Mestkelder & $\begin{array}{l}\text { Mestkelder met rechte wanden en diepte van 1,5 - 2,0 m, stal volledig } \\
\text { onderkelderd. }\end{array}$ \\
\hline Aantal plaatsen & $30 \%$ van het aantal melkkoeien. \\
\hline Groepsgrootte & Afhankelijk van het aantal melkkoeien \\
\hline \multicolumn{2}{|l|}{ Klimaat } \\
\hline Ventilatie & $\begin{array}{l}\text { Natuurlijk geventileerde stal met handmatig regelbare luchtinlaten in de } \\
\text { zijgevels en luchtafvoer via niet regelbare open nok. }\end{array}$ \\
\hline Verwarming & Geen verwarming. \\
\hline Isolatie & Geen dakisolatie. \\
\hline \multicolumn{2}{|l|}{ Voeding } \\
\hline Voervoorziening & Voerhek (55 - 65 cm vreetplaatsbreedte per dier), drinkwaterbak. \\
\hline Voermethode & Ruwvoer \\
\hline Ruwvoer & Noord-West: grassilage; Zuid-Oost: grassilage, beperkt snijmais \\
\hline Krachtvoer & Overige rundveebrok \\
\hline Vochtrijk krachtvoer & N.v.t. \\
\hline Rantsoen & Noord-West \\
\hline Weidegras, ds kg/jr & 955 \\
\hline Graskuil en hooi, ds kg/jr & 1.966 \\
\hline Snijmais, ds kg/jr & 175 \\
\hline (Kunst)melk, ds kg/jr & N.v.t. \\
\hline Overig krachtvoer, ds kg/jr & 81 \\
\hline $\begin{array}{l}\text { Voeropname, ds kg/dag per } \\
\text { dier }\end{array}$ & 8,2 \\
\hline Water/voer & N.v.t. \\
\hline \multicolumn{2}{|l|}{ Productie $^{1}$} \\
\hline Groeitraject, kg (WUM)2 & $320-525$ \\
\hline Voerconversie & N.v.t. \\
\hline Uitval, \% & 2 \\
\hline \multicolumn{2}{|l|}{ Overig } \\
\hline Reiniging/ontsmetten & N.v.t. \\
\hline Mestmanagement & Mestkelder onder roostervloer \\
\hline Mestverwijderfrequentie & 2 maal per jaar \\
\hline
\end{tabular}

1: Productiecijfers kennen geen onderscheid tussen NW en ZO

2: Voeropname oplopend van 5400-7500 VEM per dier per dag 


\subsubsection{Vleeskalveren}

Bij vleeskalveren is sprake van twee onderscheiden marktsegmenten met eveneens onderscheiden huisvesting en verzorging. Blankvleeskalveren worden tot ze slachtrijp zijn in hoofdzaak gevoerd met kunstmelk. Het vlees wordt vermarkt als "veal" (kalfsvlees). Rosékalveren krijgen maar beperkt kunstmelk en worden snel aan vast voer gewend en op een oudere leeftijd ( 8 maanden en ouder) geslacht en als "young beef" op de markt gebracht. In de Rav wordt geen onderscheid gemaakt tussen beide segmenten, maar in de praktijk kunnen maatregelen voor blank- en rosévleeskalveren verschillend zijn, zeker als het gaat om voer- en managementmaatregelen. De huidige praktijk in de kalverhouderij is geen statisch gebeuren en kan door zijn structuur snel reageren op ontwikkelingen in de markt. Wanneer de markt bijvoorbeeld vraagt om 'veal' in plaats van 'young beef' levert een kalverhouder het dier twee maanden eerder. Wanneer de markt vraagt om rosévlees kan de kalverhouder in dezelfde stal voor blankvleeskalveren, de volgende ronde rosévleeskalveren plaatsen. Met name voer en management maken het verschil tussen deze twee diercategorieën. Daarom zullen voer- en managementmaatregelen waar de PAS in voorziet anders uitpakken voor blank-, dan wel rosévleeskalveren. Daarnaast speelt nog het leeftijdsverschil. Om die redenen worden hier voor meerdere categorieën vleeskalveren referentiesystemen opgenomen. Zoals in hoofdstuk 2 beschreven zal bij invoering van maatregelen in de PAS-regeling voorzien moeten worden in de mogelijkheid het effect van de maatregel te monitoren. Dat geldt zeker voor rosé- en blankvleeskalveren.

\subsubsection{Blankvleeskalveren}

Tabel 3 PAS Referentie voor een stal voor blank vleeskalveren

\begin{tabular}{|c|c|}
\hline Bedriffissysteem & Blankvleeskalveren, volledig rooster, 7 \% leegstand \\
\hline \multicolumn{2}{|l|}{ Huisvesting } \\
\hline Staloppervlak & Afdelingsgrootte 40 - 80 kalveren. \\
\hline Loopoppervlak & $\begin{array}{l}1,8 \mathrm{~m}^{2} \text { loopoppervlak / dier, uitgevoerd met een volledige roostervloer } \\
\text { van hard hout (balk-/spleetbreedte } 80 / 25-30 \mathrm{~mm} \text { ). }\end{array}$ \\
\hline Hokafmetingen & Hokken ca 2,25 m diep. \\
\hline Mestkelder & $\begin{array}{l}\text { Mestkelder met rechte wanden en diepte van 0,4-0,8 m, hok volledig } \\
\text { onderkelderd. }\end{array}$ \\
\hline Groepsgrootte & 5 - 8 kalveren \\
\hline \multicolumn{2}{|l|}{ Klimaat } \\
\hline Ventilatie & Mechanische ventilatie met luchtaanvoer via het voerpad. \\
\hline Verwarming & $\begin{array}{l}\text { Mogelijkheid tot voorverwarming van ingaande lucht bij opzet van de } \\
\text { kalveren. }\end{array}$ \\
\hline Isolatie & Muur- en dakisolatie. \\
\hline \multicolumn{2}{|l|}{ Voeding } \\
\hline Voervoorziening & $\begin{array}{l}\text { Lange trog voor gelijktijdige kalvermelkverstrekking per hok. Nippel } \\
\text { voor aanvullend drinkwater. }\end{array}$ \\
\hline Voermethode & $\begin{array}{l}\text { Tweemaal daags warme kalvermelk volgens voerschema. Daarnaast } \\
\text { beperkt ruwvoer (oplopend tot } 250 \mathrm{~g} / \text { dier/dag) in de vorm van } \\
\text { gehakseld stro of strobrok. }\end{array}$ \\
\hline Kunstmelkpoeder, ds kg/jr & S \\
\hline Vochtrijk krachtvoer, ds kg/jr & N.v.t. \\
\hline $\begin{array}{l}\text { Eiwitrijk krachtvoer (opfokbrok), ds } \\
\mathrm{kg} / \mathrm{jr}\end{array}$ & N.v.t. \\
\hline $\begin{array}{l}\text { Overig krachtvoer / melkvervangermix, } \\
\text { ds } \mathrm{kg} / \mathrm{jr}\end{array}$ & 343 \\
\hline Snijmaïs, ds kg/jr & N.v.t. \\
\hline Stro, ds kg/jr & 30 \\
\hline Voeropname, ds kg/dag per dier & 2,4 \\
\hline Waterverbruik & $9 \mathrm{~m}^{3}$ per kalverplaats/jr \\
\hline \multicolumn{2}{|l|}{ Productie } \\
\hline Groeitraject, kg & $45-225$ \\
\hline Mestperiode (dagen) & 180 \\
\hline Groei, gr/dag per dier & ca 990 \\
\hline $\begin{array}{l}\text { Voeropname, } \mathrm{kg} / \mathrm{dier} \\
\text { per dag en per ronde }\end{array}$ & $\begin{array}{l}1,53 \mathrm{~kg} \text { kunstmelk / dag ( } 275 \mathrm{~kg} \text { per ronde) } \\
1,1 \mathrm{~kg} \text { melkvervangermix / dag ( } 200 \mathrm{~kg} / \text { ronde) } \\
85 \mathrm{~g} \text { stro/dag ( } 15 \mathrm{~kg} / \text { ronde) }\end{array}$ \\
\hline Voerconversie & N.v.t. \\
\hline Uitval, \% & 3 \\
\hline \multicolumn{2}{|l|}{ Overig } \\
\hline Reiniging/ontsmetten & Reiniging en ontsmetting na iedere ronde \\
\hline Mestmanagement & Ondiepe mestkelder $(40-80 \mathrm{~cm})$ onder het hele hok \\
\hline Mestverwijderfrequentie & $\begin{array}{l}\text { Regelmatige mestafvoer naar een afgesloten opslag of naar een } \\
\text { kalvergierverwerkingsinstallatie }\end{array}$ \\
\hline
\end{tabular}




\subsubsection{Rosévleeskalveren}

Bij rosévleeskalveren worden twee houderijfasen onderscheiden: de startersfase waarin de jonge kalveren worden opgevangen en geleidelijk van vloeibaar voer overschakelen naar vast voer. Daarnaast kennen we de afmestfase waarin de starters slachtrijp worden gemaakt om als jong rosékalf (op een leeftijd van bijna acht maanden; young beef) of als oud rosékalf op een leeftijd van gemiddeld bijna tien maanden te worden afgeleverd. De startersfase vindt in afzonderlijke huisvesting plaats en veelal ook op hiervoor gespecialiseerde bedrijven. Het onderscheid tussen jong en oud rosé in de mestfase heeft geen huisvestingsachtergrond en is vooral zaak van voeding en management. In tabellen $4 \mathrm{a}$ (startkalf) en $4 \mathrm{~b}$ (jong en oud rosé) zijn de kenmerken van alle drie verschijningsvormen samengevat.

Tabel 4a PAS Referentie voor een stal in de vleeskalverhouderij, rosé startkalveren

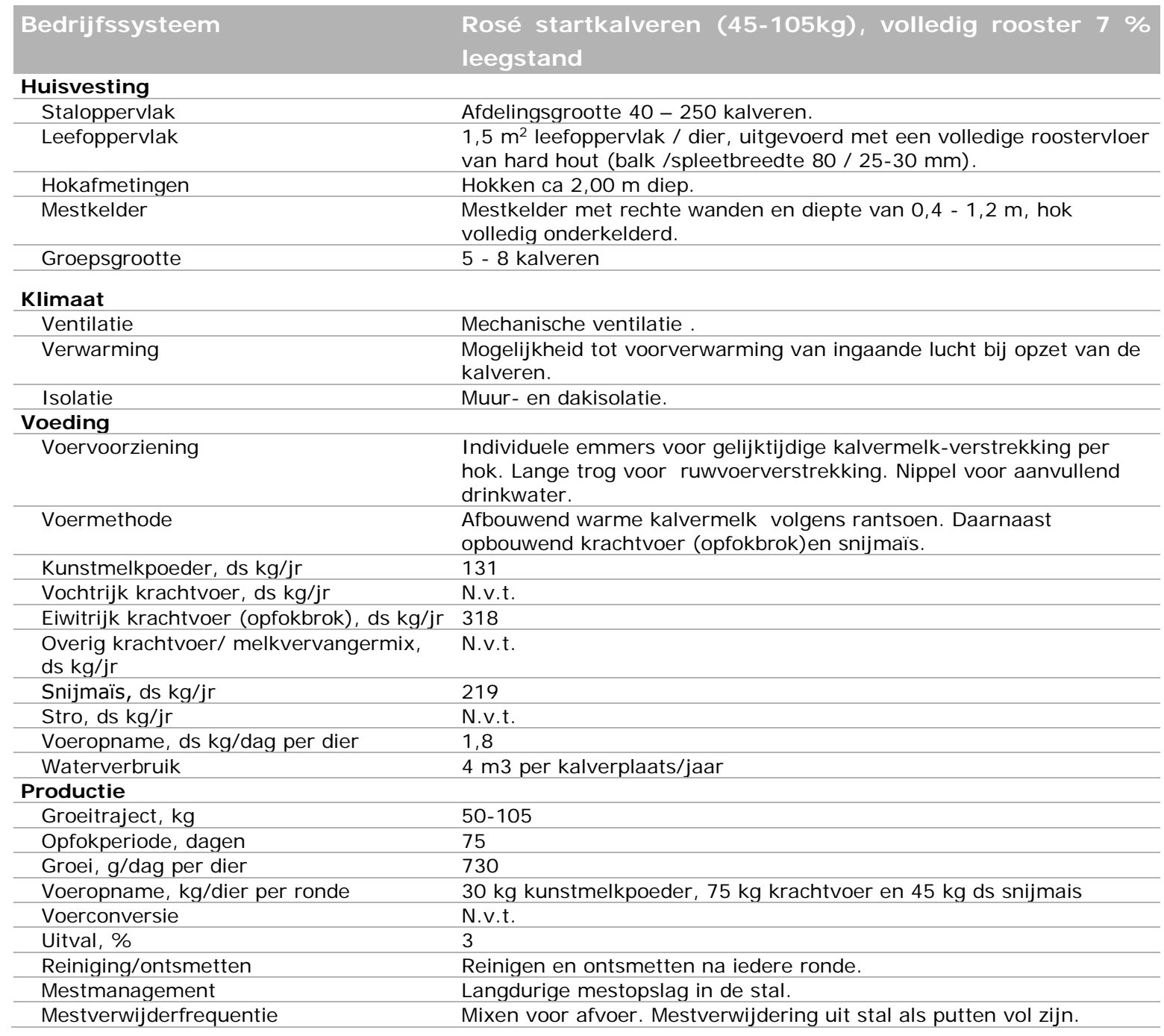


Tabel 4b PAS Referentie voor een stal in de vleeskalverhouderij, jong en oud rosé vleeskalveren

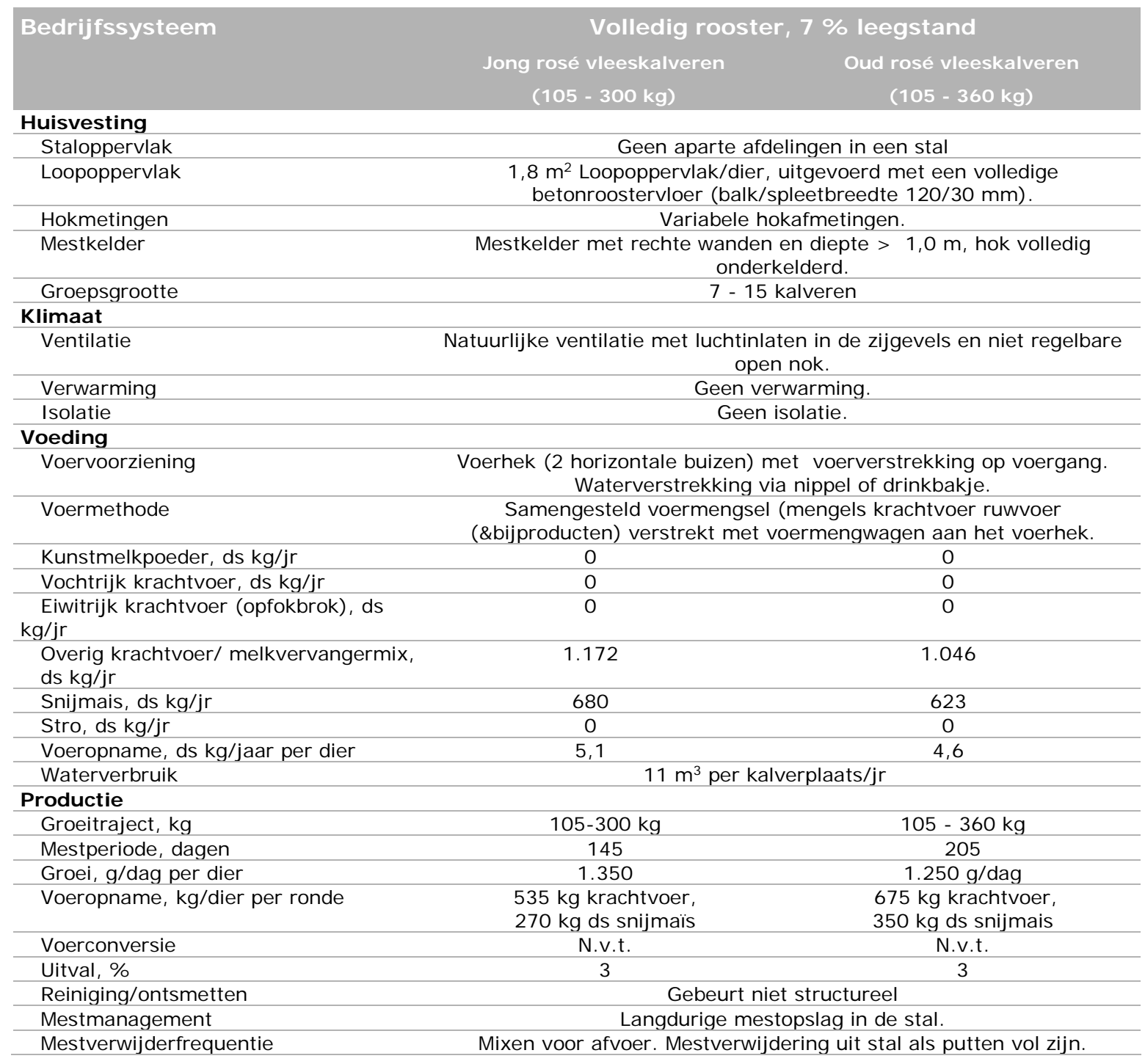




\subsection{Varkens}

\subsubsection{Biggen}

De huisvesting van biggen is uniform over heel Nederland. De biggen worden na het spenen in een opfokafdeling geplaatst waar ze verblijven tot moment van afleveren op circa $25 \mathrm{~kg}$. De uitgangspunten voor de biggenopfok staan in tabel 5 .

Tabel 5 PAS Referentie voor een stal voor biggenopfok

\begin{tabular}{|c|c|}
\hline Bedrijfissysteem & Groepshuisvesting, all-in - all-out, leegstand 9\% \\
\hline \multicolumn{2}{|l|}{ Huisvesting } \\
\hline Leefoppervlak & $0,3 \mathrm{~m}^{2}$ volledig rooster van kunststof of van metaal \\
\hline Hokafmetingen & Niet relevant (voor emissie) bij volledig rooster \\
\hline Mestkelder & Mestkelder met rechte wanden en diepte van 1,0 m \\
\hline Groepsgrootte & $12-15$ \\
\hline Klimaat & $\begin{array}{l}\text { Debiet, verwarming en temperatuur volgens richtlijn Klimaatplatform voor } \\
\text { plafondventilatiesysteem. In deze tabel worden de hoogste waarden } \\
\text { aangehouden. }\end{array}$ \\
\hline Ventilatie & $\begin{array}{l}\text { Mechanisch, indirecte luchtaanvoer via ventilatieplafond, luchtafvoer via } \\
\text { ventilatiekoker in plafond. }\end{array}$ \\
\hline Verwarming & Voorverwarming van inkomende lucht en ruimteverwarming \\
\hline \multicolumn{2}{|l|}{ Voeding } \\
\hline Voervoorziening & Minimaal 1 voerplaats per 12 biggen, voerbak voor in het hok, apart drinkbakje \\
\hline Voermethode & Volgtijdig (dieren eten na elkaar), onbeperkt, droogvoer \\
\hline (Ruw) eiwitgehalte voer, $\mathrm{g} / \mathrm{kg}$ & 175 \\
\hline Verteringscoëfficiënt voer & 0,84 \\
\hline VNSP ${ }^{1)}, \mathrm{g} / \mathrm{kg}$ & 105 \\
\hline $\mathrm{dEB}^{11}, \mathrm{mEq}$ & 180 \\
\hline Ca-bron & Ca-carbonaat (krijt) \\
\hline Water/voer & 3,2 \\
\hline \multicolumn{2}{|l|}{ Productie } \\
\hline Groeitraject, kg & $8-25$ \\
\hline Groei, g/dag per dier & 340 \\
\hline Voeropname, kg/dag per dier & 0,56 \\
\hline Voerconversie, kg/kg & 1,63 \\
\hline Uitval, \% & 2,3 \\
\hline Reiniging/ontsmetten & $\begin{array}{l}\text { Reiniging en ontsmetting na elke ronde; schoonmaakwater } 12 \text { L/biggenplaats per } \\
\text { ronde }\end{array}$ \\
\hline Mestmanagement & Mestkelder alleen onder de roostervloer \\
\hline Mestverwijderfrequentie & $1 \times$ per maand \\
\hline
\end{tabular}




\subsubsection{Kraamzeugen}

De huisvesting van kraamzeugen is uniform over heel Nederland. De zeugen verblijven in het kraamhok van circa één week voor het werpen tot aan het moment van spenen van de biggen. De uitgangspunten voor de kraamzeugen staan in tabel 6.

Tabel 6 PAS Referentie voor een stal voor kraamzeugen

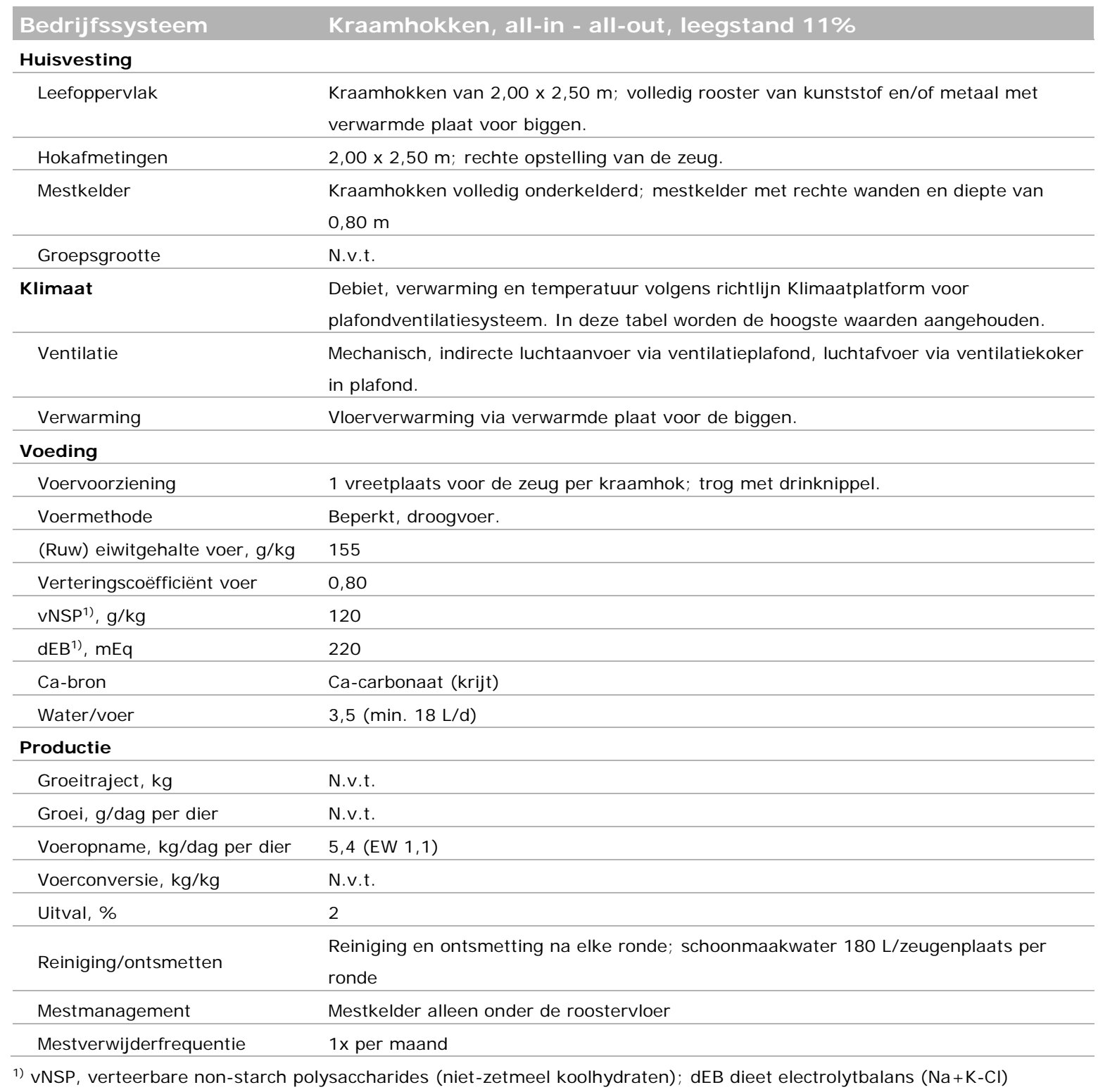




\subsubsection{Guste en dragende zeugen}

De huisvesting van guste en dragende zeugen is uniform over heel Nederland. De dragende zeugen verblijven in groepshuisvesting vanaf vier dagen na dekken tot één week voor het werpen van de biggen. De uitgangspunten voor de guste en dragende zeugen staan in tabel 7.

Tabel 7 PAS Referentie voor een stal voor guste en dragende zeugen

\begin{tabular}{|c|c|}
\hline \multicolumn{2}{|l|}{ Huisvesting } \\
\hline Leefoppervlak & $\begin{array}{l}2,25 \mathrm{~m}^{2} \text { totaal oppervlak, waarvan } 0,95 \mathrm{~m}^{2} \text { roostervloer van beton en } 1,30 \mathrm{~m}^{2} \\
\text { aaneengesloten dichte vloer. }\end{array}$ \\
\hline Hokafmetingen & Allerlei vormen zijn mogelijk, waarbij er weinig bevuiling optreedt van de dichte vloer. \\
\hline Mestkelder & Mestkelder met rechte wanden en diepte van $1,0 \mathrm{~m}$. \\
\hline Groepsgrootte & 40 \\
\hline Klimaat & $\begin{array}{l}\text { Debiet, verwarming en temperatuur volgens richtlijn Klimaatplatform voor } \\
\text { plafondventilatiesysteem. In deze tabel worden de hoogste waarden aangehouden. }\end{array}$ \\
\hline Ventilatie & $\begin{array}{l}\text { Mechanisch, indirecte luchtaanvoer via ventilatieplafond, luchtafvoer via ventilatiekoker } \\
\text { in plafond. }\end{array}$ \\
\hline Verwarming & Geen. \\
\hline \multicolumn{2}{|l|}{ Voeding } \\
\hline Voervoorziening & Minimaal 1 voerplaats per 55 zeugen, aparte drinkbakjes. \\
\hline Voermethode & Volgtijdig, beperkt, droogvoer. \\
\hline (Ruw) eiwitgehalte voer, g/kg & 130 \\
\hline Verteringscoëfficiënt voer & 0,69 \\
\hline VNSP $^{1)}, \mathrm{g} / \mathrm{kg}$ & 180 \\
\hline $\mathrm{dEB}^{1)}, \mathrm{mEq}$ & 280 \\
\hline Ca-bron & Ca-carbonaat (krijt) \\
\hline Water/voer & 2,8 \\
\hline \multicolumn{2}{|l|}{ Productie } \\
\hline Groeitraject, kg & N.v.t. \\
\hline Groei, g/dag per dier & N.v.t. \\
\hline Voeropname, kg/dag per dier & $2,80 \quad(E W 0,97)$ \\
\hline Voerconversie, $\mathrm{kg} / \mathrm{kg}$ & N.v.t. \\
\hline Uitval, \% & 4 \\
\hline Reiniging/ontsmetten & $\begin{array}{l}\text { Reiniging en ontsmetting na elke ronde; schoonmaakwater } 50 \text { L/zeugenplaats, } 1 \times \text { per } \\
\text { half jaar. }\end{array}$ \\
\hline Mestmanagement & Mestkelder alleen onder de roostervloer. \\
\hline Mestverwijderfrequentie & $1 \times$ per 2 maanden. \\
\hline
\end{tabular}




\subsubsection{Vleesvarkens}

De huisvesting van vleesvarkens is uniform over heel Nederland. De vleesvarkens worden vanaf opleg op circa $25 \mathrm{~kg}$ in een afdeling geplaatst waar ze verblijven tot moment van afleveren op circa $118 \mathrm{~kg}$. De uitgangspunten voor de vleesvarkens staan in tabel 8.

Tabel 8 PAS Referentie voor een stal voor vleesvarkens en opfokzeugen

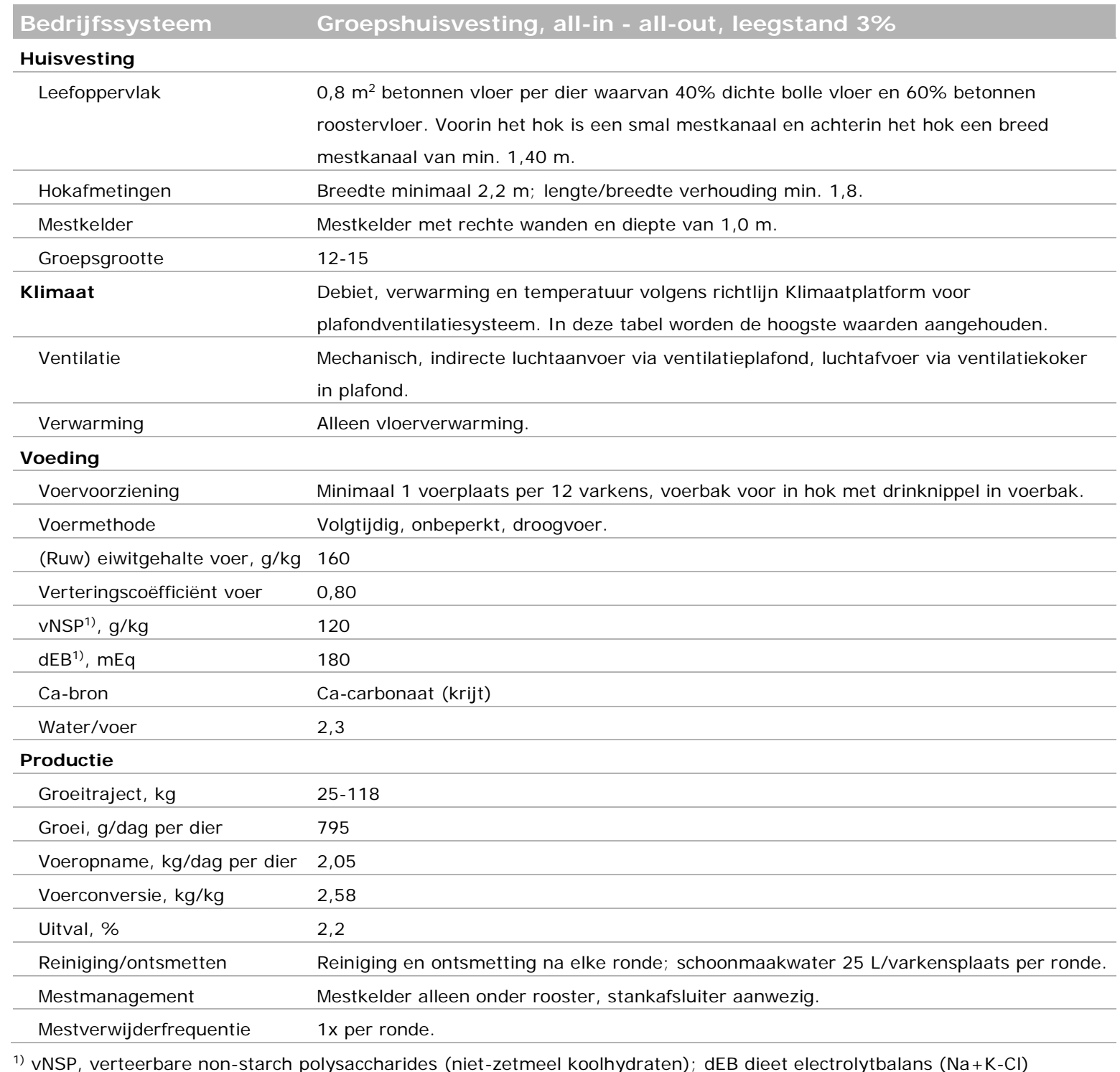




\subsection{Pluimvee}

\subsubsection{Opfokleghennen}

$\mathrm{Bij}$ opfokleghennen is een onderverdeling gemaakt naar een drietal gangbare huisvestingssystemen: grond- of scharrelhuisvesting, volièrestallen en kooihuisvesting. Oorzaak hiervan ligt in de omschakeling naar de alternatieve huisvestingssystemen (scharrel en volière) bij leghennen op basis van het verbod op de traditionele batterijhuisvesting. De verschillen tussen de systemen zijn te groot om voor deze diergroep slechts één systeem als referent aan te wijzen.

Tabel 9 PAS Referentie voor een stal voor opfok leghennen

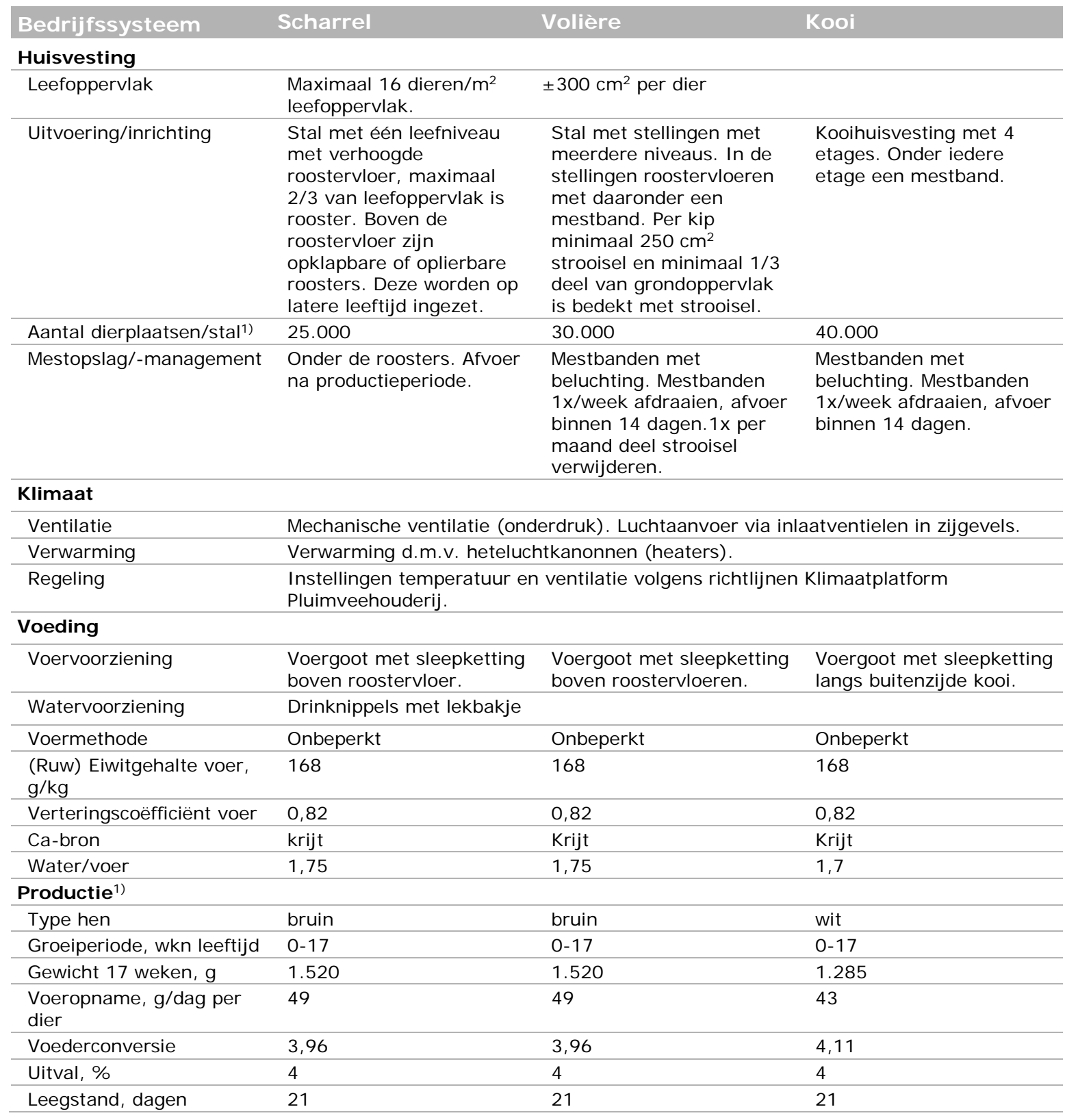

1) Gebaseerd op WUM, LEI-BIN en KWIN-Veehouderij 2013-2014

\subsubsection{Leghennen}

Toelichting bij bedrijfssysteem

Net als bij opfokleghennen is bij leghennen ook een opsplitsing gemaakt naar een drietal huisvestingssystemen die veel voorkomen: scharrel- of grondhuisvesting, volièrestallen en kooihuisvesting. Bij kooihuisvesting is uitgegaan van de Kolonie omdat dit systeem in de toekomst toegestaan blijft. In 2013 waren er ook bedrijven met verrijkte kooien, maar vanaf 2020 zijn deze verboden. De Kolonie is een grotere variant van de verrijkte kooien. 


\section{Toelichting productie}

De productiegegevens zijn gebaseerd op de gemiddelde waarden van de drie productiesysteem in 2012/2013 zoals die zijn opgenomen in KWIN 2014-2015: gewogen gemiddelde eiproductie was 19,0 $\mathrm{kg}$ met een voeropname van $119 \mathrm{~g} / \mathrm{d}$ gebaseerd op gegevens uit de legmanager Agrovision. Deze cijfers komen aardig overeen met de WUM cijfers. WUM berekent deze gegevens eveneens, maar kan geen onderscheid maken tussen productiesystemen. Toch komen zij uit op een vergelijkbaar gemiddelde eiproductie van $19,2 \mathrm{~kg} / \mathrm{hen} / \mathrm{j}$ aar en voeropname van $116 \mathrm{~g} / \mathrm{hen} / \mathrm{d}$ (gebaseerd op gegevens uit LEI BIN voor voerverbruik en eiproductie met een verdeling van $10 \%$ hennen op kooi (wit) en $90 \%$ hennen op strooisel waarvan $30 \%$ wit en $70 \%$ bruin).

Tabel 10 PAS Referentie voor een stal voor leghennen

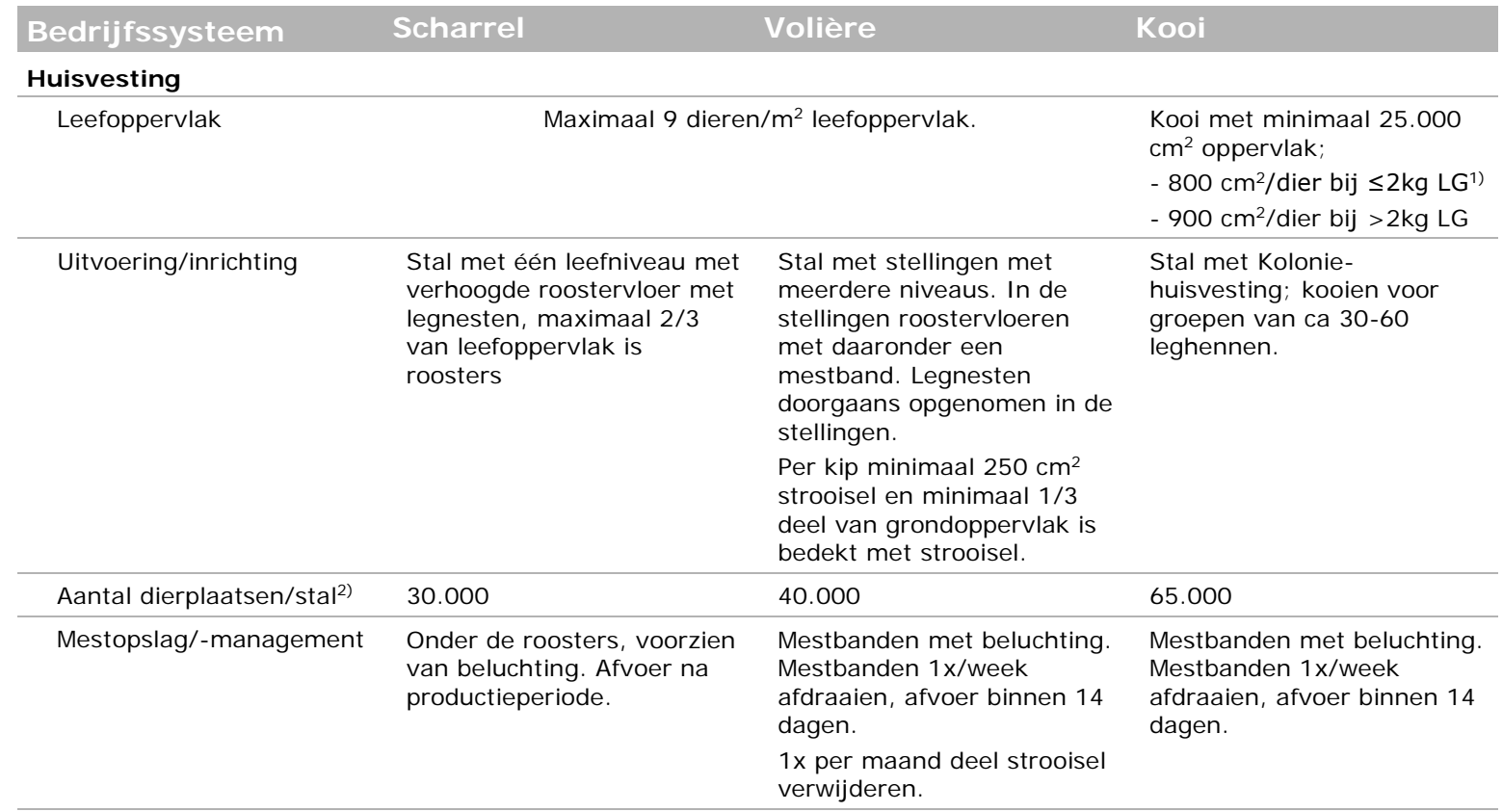

\begin{tabular}{|c|c|c|c|}
\hline \multicolumn{4}{|l|}{ Klimaat } \\
\hline Verwarming & \multicolumn{3}{|c|}{ Alleen opwarming stal voorafgaand aan opvang van jonge hennen. } \\
\hline Regeling & \multicolumn{3}{|c|}{$\begin{array}{l}\text { Instellingen temperatuur en ventilatie volgens richtlijnen Klimaatplatform } \\
\text { Pluimveehouderij. }\end{array}$} \\
\hline \multicolumn{4}{|l|}{ Voeding } \\
\hline Watervoorziening & Drinknippels met lekbakje & Drinknippels met lekbakje & Drinknippels met lekbakje \\
\hline Voermethode & Onbeperkt & Onbeperkt & Onbeperkt \\
\hline $\begin{array}{l}\text { (Ruw) Eiwitgehalte voer, } \\
\mathrm{g} / \mathrm{kg}\end{array}$ & 163 & 163 & 163 \\
\hline Water/voer & 1,75 & 1,75 & 1,75 \\
\hline \multicolumn{4}{|l|}{ Productie $^{2)}$} \\
\hline Type hen & bruin & bruin & wit \\
\hline $\begin{array}{l}\text { Productieperiode, wkn } \\
\text { leeftijd }\end{array}$ & $17-80$ & $17-80$ & 17-91 \\
\hline $\begin{array}{l}\text { Productie, } \mathrm{kg} \text { ei/20 wkn } \\
\text { leghen per jr }\end{array}$ & 18,9 & 18,9 & 18,9 \\
\hline $\begin{array}{l}\text { Voeropname, } \\
\text { g/dag per dier }\end{array}$ & 121 & 121 & 110 \\
\hline
\end{tabular}




\subsubsection{Opfok vleeskuikenouderdieren}

De huisvesting van opfok vleeskuikenouderdieren is in Nederland uniform. De dieren worden gehouden in een stal met grondhuisvesting, waarbij hennen en hanen apart van elkaar worden gehuisvest.

Tabel 11 PAS Referentie voor een stal voor opfok vleeskuikenouderdieren

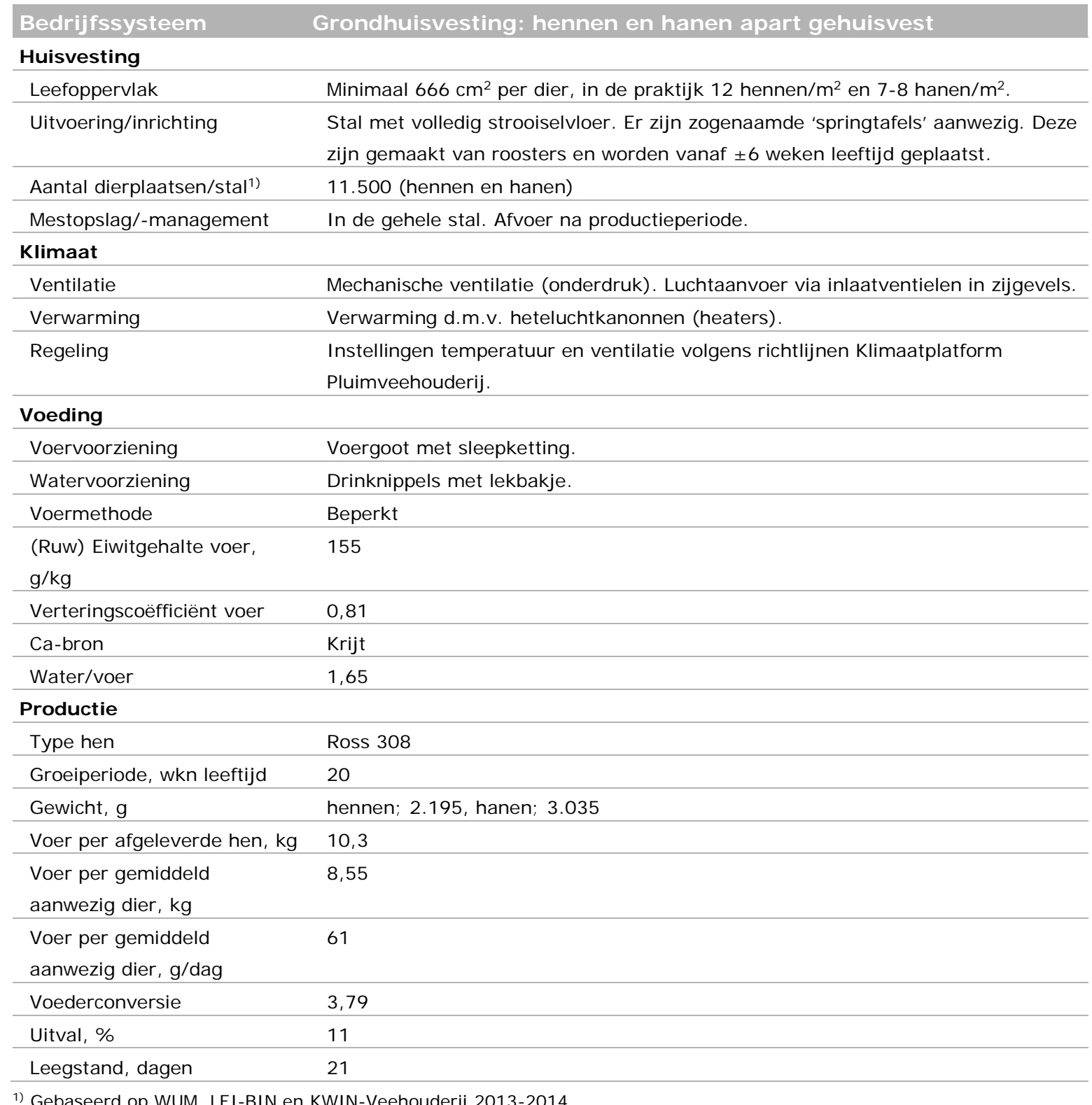

1) Gebaseerd op WUM, LEI-BIN en KWIN-Veehouderij 2013-2014 


\subsubsection{Vleeskuikenouderdieren}

De huisvesting van vleeskuikenouderdieren is in Nederland uniform. De dieren worden in een stal met grondhuisvesting gehouden, waarbij hennen en hanen samen worden gehuisvest.

Tabel 12 PAS Referentie voor een stal voor vleeskuikenouderdieren

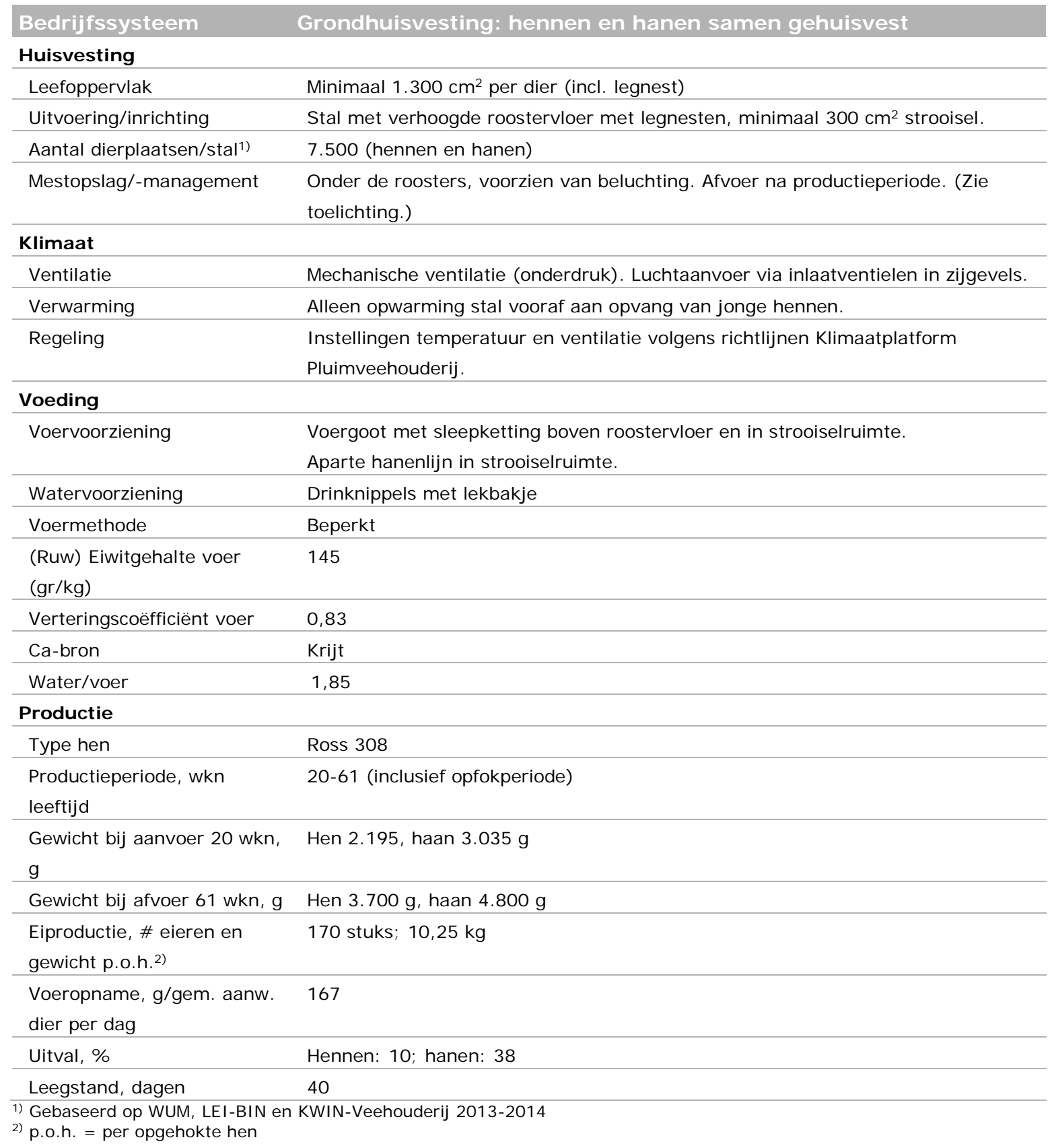

Toelichting op mestmanagement

Per 1 januari 2013 moesten alle pluimveebedrijven voldoen aan het Besluit huisvesting. Gemiddeld mocht de emissie van ammoniak op een bedrijf met vleeskuikenouderdieren niet boven de $0,435 \mathrm{~kg}$ $\mathrm{NH}_{3}$ /dierplaats/jaar zijn. Hiertoe is op veel bedrijven een stal uitgerust met een systeem dat continu $2,5 \mathrm{~m}^{3}$ lucht/dier per uur over de mest blaast van $24^{\circ} \mathrm{C}$. Dit systeem heeft een emissiefactor van $0,250 \mathrm{~kg} \mathrm{NH} /$ dierplaats/jaar, maar geeft hoge kosten. Omdat 2013 nog een soort overgangsjaar was, kan het zijn dat het systeem nog niet op alle bedrijven operationeel was. Vanwege het nog maar beperkt toepassen (o.a. vanwege de hoge kosten) is het systeem niet als referent systeem opgenomen. 


\subsubsection{Vleeskuikens}

De huisvesting van vleeskuikens is in 2013 in Nederland nog behoorlijk uniform. De dieren worden in een stal met volledig strooisel gehouden, waarbij hennetjes en haantjes samen worden gehuisvest. Er zijn ontwikkelingen naar aan de ene kant lagere bezettingen bij de traditionele grondstallen (met trager groeiende kuikens) en etagesystemen met een hoge mate van mechanisering aan de andere kant. Deze laatste ontwikkeling is nog maar beperkt.

Tabel 13 PAS Referentie voor een stal voor vleeskuikens

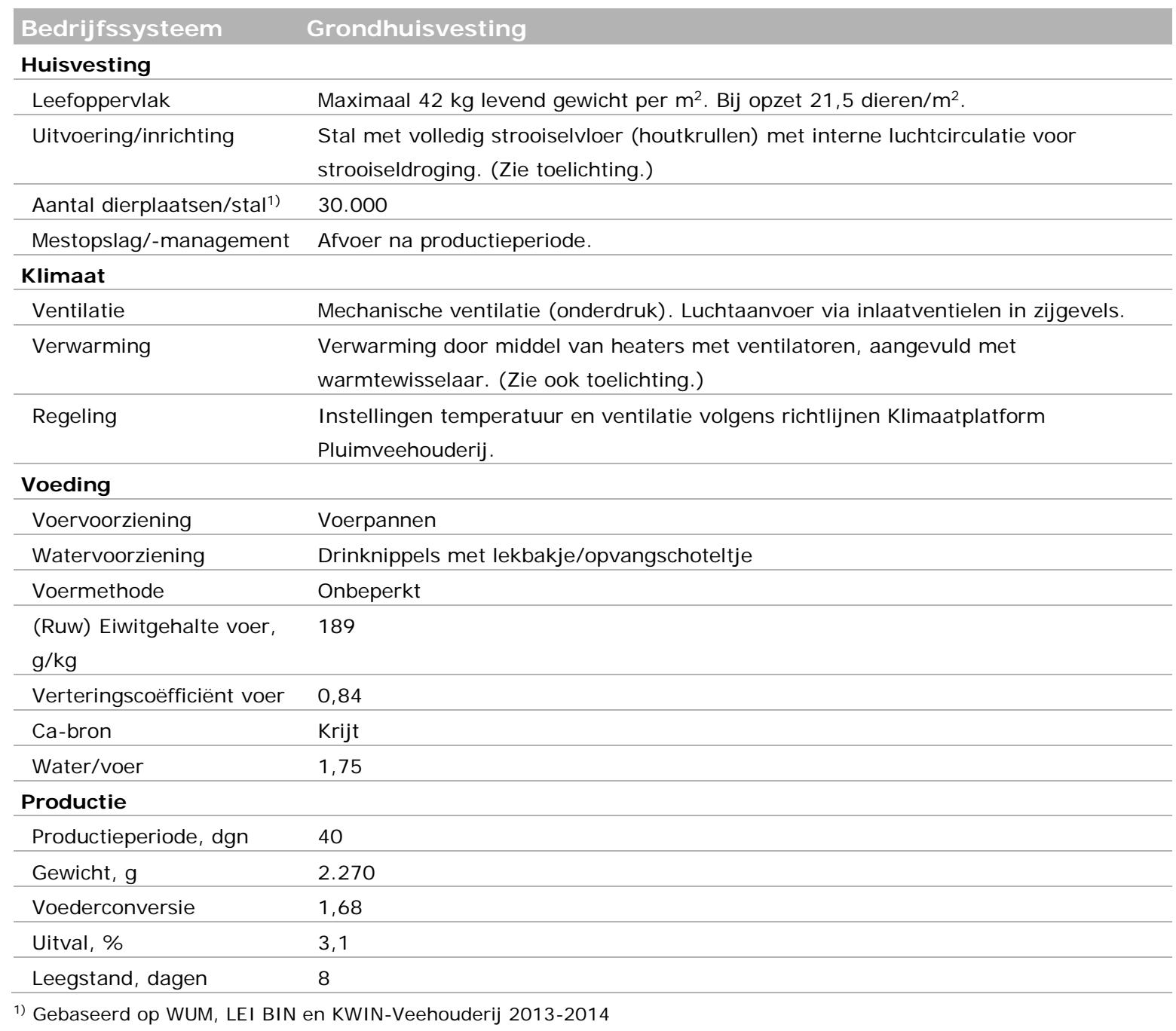

\section{Toelichting op luchtcirculatie en verwarming}

Per 1 januari 2013 moesten alle pluimveebedrijven voldoen aan het Besluit huisvesting. Gemiddeld mocht de emissie van ammoniak op een vleeskuikenbedrijf niet boven de $0,045 \mathrm{~kg} \mathrm{NH} /$ dierplaats/jaar zijn. Hiertoe zijn op veel bedrijven een of meerdere stallen uitgerust met een van de systemen die gebruik maken van interne luchtcirculatie. Dit kunnen zowel de zogenaamde Wesselman-heaters zijn (heaters met ventilatoren) als heteluchtkanonnen met rookgasafvoer (indirect gestookte heaters). In veel gevallen is om te besparen op de stookkosten, ook een warmtewisselaar geïnstalleerd. 



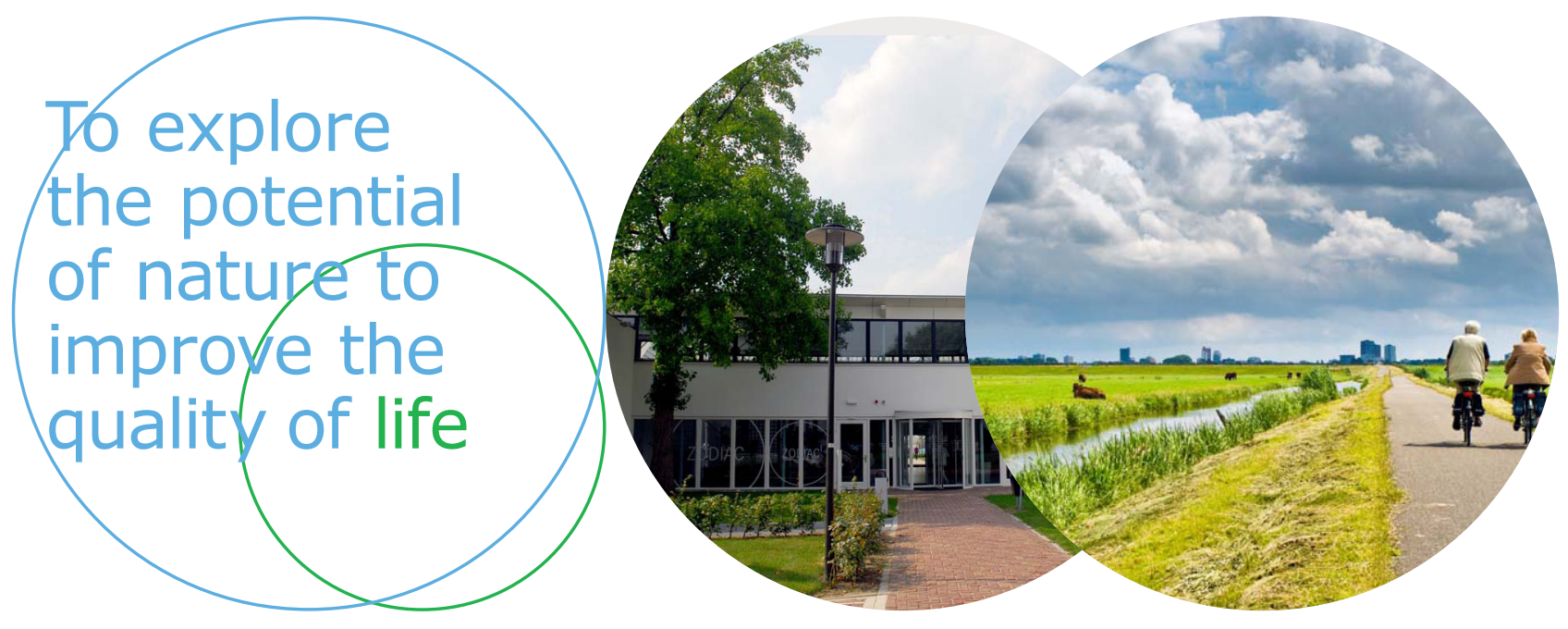

Wageningen Livestock Research Postbus 338

Wageningen Livestock Research ontwikkelt kennis voor een zorgvuldige en $6700 \mathrm{AH}$ Wageningen

T 0317483953

renderende veehouderij, vertaalt deze naar praktijkgerichte oplossingen en innovaties, en zorgt voor doorstroming van deze kennis. Onze wetenschappelijke E info.livestockresearch@wur.nl www.wur.nl/ livestock-research kennis op het gebied van veehouderijsystemen en van voeding, genetica, welzijn en milieu-impact van landbouwhuisdieren integreren we, samen met onze klanten, tot veehouderijconcepten voor de $21 \mathrm{e}$ eeuw.

De missie van Wageningen University \& Research is 'To explore the potential of nature to improve the quality of life'. Binnen Wageningen University \& Research bundelen 9 gespecialiseerde onderzoeksinstituten van Stichting Wageningen Research en Wageningen University hun krachten om bij te dragen aan de oplossing van belangrijke vragen in het domein van gezonde voeding en leefomgeving. Met ongeveer 30 vestigingen, 6.500 medewerkers en 10.000 studenten behoort Wageningen University \& Research wereldwijd tot de aansprekende kennisinstellingen binnen haar domein. De integrale benadering van de vraagstukken en de samenwerking tussen verschillende disciplines vormen het hart van de unieke Wageningen aanpak. 